\title{
Tablespoon Dosing Unit
}

National Cancer Institute

\section{Source}

National Cancer Institute. Tablespoon Dosing Unit. NCI Thesaurus. Code C48541.

A unit of volume informally used in pharmacy. Under the metric system the tablespoon has been standardized at 15 milliliters in the US, Britain, Canada, and New Zealand, and at 20 milliliters in Australia and some European countries. 